\title{
SOMATIC CONVERSION IN THE HEREDITY OF THE CRUCIATA CHARACTER IN CENOTHERA
}

\author{
O. RENNER \\ Botanisches Institut der Universität München
}

Received 23.vii. $5^{8}$

\section{INTRODUCTION}

In the genera Epilobium and Enothera, types with sepaloid petals are known and these are called cruciata forms. The sepaloidy expresses itself in the form, colour, anatomical structure and mode of development of the petals. The character shows single factor Mendelian segregation in crosses of $E$. hirsutum var. cruciatum with the normal types of $E$. hirsutum and $E$. parviflorum. The normal is dominant.

In Enothera, likewise, normal $(\mathrm{Cr})$ can be clearly dominant to cruciata $(c r)$. Usually, however, dominance is variable and the form of the corolla fluctuates between $\mathrm{Cr}$ and $\mathrm{cr}$ on different individuals or even on the same individual. This variability has a genotypic basis for the extreme flower forms commonly breed more or less true with selfing. The cause of the variability is certainly not somatic crossingover. Mutation must therefore be taking place.

\section{SOME EXPERIMENTS}

The most exact study has been made of the cross between the following :-

(i) Normal-flowered $E$. biennis L. (heterogamous : albicans . rubens) ;

(ii) The strictly cruciate $E$. atrovirens Shull et Bartl. (heterogamous : pingens. flectens).

The hybrid $\mathscr{E}$. (atrovirens $\times$ biennis) pingens . rubens, which is known as pictirubata, forms only pure pingens eggs and pure rubens pollen. In meiosis there are two rings: (10) +(4). Combinations of five pingens and two rubens chromosomes and vice versa might therefore be expected. They are, however, eliminated and do not appear in the progeny. Indeed they appear in the pollen as dead and empty grains additional to the active rubens and inactive pingens, which are both full grains.

$\mathrm{F}_{1}$ plants with normal petals give almost all their selfed progeny normal ; cruciata plants give almost all cruciata. The results of selfing from 1949 to 1954 are shown in table $\mathrm{I}$.

For analysis of the gametes of hybrids, cruciata types were selected whose $\mathrm{cr}$ alleles showed themselves entirely recessive in crosses with $C r$. Such were a small-flowered $\mathcal{E}$. Lamarckiana cruciata (with flowers 
no larger than biennis) of unknown origin and or sp-blandina. Thus :Cr-pictirubata $\times$ cr-Lamarckiana gives $\left\{\begin{array}{l}\text { normal }(C r): \text { pingens } . \text { gaudens (pictileta) } \\ \text { normal }(C r): \text { pingens . velans (pictivelutina). }\end{array}\right.$

Reciprocal cross gives

$$
\begin{cases}\text { normal }(\mathrm{Cr}): & \text { velans. rubens } \\ {[\text { dies }]} & \text { gaudens. rubens. }\end{cases}
$$

Thus all rubens pollen has $C r$ and all pingens eggs likewise have $C r$ (instead of $c r$ as expected).

Taking another experiment, the two reciprocal crosses of $\mathrm{Cr}$ pictirubata with cr-Lamarckiana or with or sp-blandina (plate I) show us (i) that almost all pingens eggs still carry $c r$ and (ii) that all rubens pollen carries $\mathrm{cr}$ instead of $\mathrm{Cr}$.

TABLE I

Progenies from E. biennis $\times$ E. atrovirens cruciata

\begin{tabular}{|c|c|c|c|c|c|c|}
\hline \multirow{2}{*}{ Parent } & \multicolumn{2}{|c|}{$\mathrm{F}_{2}$} & \multicolumn{2}{|c|}{$\mathrm{F}_{3}$} & \multicolumn{2}{|c|}{$\mathrm{F}_{2}+\mathrm{F}_{3}$} \\
\hline & $\mathrm{Cr}$ & $c r$ & $\mathrm{Cr}$ & $\mathrm{cr}$ & $\mathrm{Cr}$ & $\mathrm{cr}$ \\
\hline $\mathrm{Cr}$ & 309 & 2 & I 59 & o & 468 & 2 \\
\hline$c r$ & 15 & 243 & 4 & 145 & I9 & 388 \\
\hline
\end{tabular}

The $\mathrm{cr}$ - $\mathrm{Cr}$ heterozygotes have therefore become homozygotes : partly $\mathrm{Cr}$ - $\mathrm{Cr}$ and partly $c r-c r$. Such transformation of one gene under the influence of its allele Winkler (I930) described as conversion. In our case it is a question of a monogenic conversion; moreover it is a somatic conversion while Winkler was considering the possibility of a reciprocal transformation occurring at meiosis.

The $\mathrm{Cr}$ homozygotes, as we saw, breed true on selfing. If the $\mathrm{cr}$ homozygotes "segregate" Cr plants we have to assume that it is the result, not of recombination by way of crossing-over, but of mutation or conversion. In later gencrations the $c r$ condition can be almost as constant as the $C r$.

If cr-pictirubata is back-crossed with Cr-biennis pollen the result is most surprising : the whole progeny is Cr-pictirubata. The $\mathrm{cr}$ allele in pingens, which showed itself as active in conversion, or capable of causing conversion, when it first made contact with Cr-rubens, is thus altered in its condition. It is weakened, shocked or "shaken" as it were, and goes under on another encounter with a fresh $\mathrm{Cr}$.

Similarly the cross cr-atrovirens $\times$ Cr-pictirubata has mostly cruciata progeny. The $C r$ in rubens is thus also shaken by contact with cr pingensalthough at first it has the upper hand. Corresponding results, showing the weakening of one allele by contact with the other, have come from several other combinations. 
Back-crossing Cr-pictirubata with cr-atrovirens pollen we should now expect to give only cr-pingens . flectens (pictiflexa). According to its complexes pictiflexa is no other than atrovirens. The progenies of I953 had in fact mostly sepaloid petals :

$$
205 \mathrm{cr}: 33 \text { intermediate : } 55 \mathrm{Cr} \text {. }
$$

But in the first experiment of 1926 all pictiflexa had been normal. So were all pictirubata from the cross Cr-pictirubata $\mathrm{F}_{1} \times$ biennis, v. cruciata. At that time, therefore, the pingens complex was much more inclined to be converted from $\mathrm{cr}$ to stable $\mathrm{Cr}$ than it was thirty years later. Such shifts have been repeatedly observed in the "strength" in the activity relations with the conflicting allele.

Crossing of normal $\mathscr{E}$. biennis with the same small-flowered $c r$ Lamarckiana yields :

$$
\left\{\begin{array}{l}
\text { normal, albicans. gaudens (albilata) } \\
\text { normal, albicans . velans (albivelutina) }
\end{array}\right.
$$

If these two twin hybrids are crossed with one another reciprocally the combinations produced, gaudens. velans or velans. gaudens (which reconstitute Lamarckiana), are mostly $C r$. But both complexes were originally $c r$.

Thus through living together with Cr-albicans the $\mathrm{cr}$ allele is in both complexes converted to $\mathrm{Cr}$. The conversion may be complete ( $59 \mathrm{Cr}$; I $8 \mathrm{Cr}$ ) or not quite complete (I $3 \mathrm{Cr}, 4$ intermediate, I $\mathrm{Cr}$ ), or slight ( $38 \mathrm{Cr}, \mathrm{i} 6 \mathrm{cr}$ ).

The individuals of $C r$-albilata and Cr-albivelutina, from whose crossing the last family arose, must have therefore still been partly $\mathrm{Cr} . \mathrm{cr}$, not yet wholly converted to $\mathrm{Cr}$. $\mathrm{Cr}$. Such wobbling in behaviour is to be found in the most various combinations. Conversion is always a potentiality. It does not show the regularity of Mendelian recombinations.

Owing to the occurrence of conversion the position of the $\mathrm{cr}$ gene in the genome is difficult to determine. Crosses of $E$. biennis to with the homozygous taxa $\mathscr{E}$. Hookeri and $\mathscr{E}$. Lamarckiana mut. blandina as Q have indicated, however, that $c r$ lies in chromosome 5.6 of rubens. This also contains the blunt calyx factor $s p$. Where 5.6 is missing as in albicans and pingens we can only say that $c r$ is in the 5 or the $6 \mathrm{arm}$. It is not certain whether crossing-over in respect of $\mathrm{Cr}$ - $\mathrm{cr}$ takes place. A decision would be useful because it would indicate if the locus was far from the ends, perhaps on the borders of euchromatin and heterochromatin.

The cross of biennis cruciata by Lamarckiana normal is especially interesting because here the influence of flower size on the expression of the cruciata character is particularly clear. The main gene for flower size, $C_{0}$ (small) and co (large) lies in the $\mathrm{I}_{3}$ or $\mathrm{I}_{4}$ segment. It is so far distal that in all complex combinations Co-co recombine freely. 
In the progeny of cr-albilata $\mathrm{F}_{1} \times$ albivelutina $\mathrm{F}_{1}$, there are three kinds of Lamarckiana (besides albivelutina) :

(i) Small-flowered individuals which have the Co of albicans in double dose. They are stable cruciata.

(ii) Intermediate-flowered $C o . c o$. They are mostly cruciata but can also be normal.

(iii) Large-flowered co .co. They are mostly normal, sometimes with slight defects in the petals, rarely cruciate. These last, largeflowered cruciate, have almost solely $\mathrm{Cr}$, i.e. normal offspring.

The stabilisation of the $\mathrm{cr}$ gene which has arisen from $\mathrm{Cr}$ by conversion is thus encouraged by the Co gene for small flowers which comes from biennis.

In the genomes of the homozygous $C$. Hookeri and $E$. blandina the $\mathrm{cr}$ allele behaves as though it were located in chromosome $5 \cdot 6$. Small-flowered and large-flowered $s p s p$ cr cr blandina are fairly constant stable cruciates. The similar spsp cr cr Hookeri, however, is stable when small-flowered. When large-flowered it remained cruciate only when it had received the red-nerve factor $R$ in heterozygous state ; this came from rubens of biennis in the $\mathrm{I} \cdot 2$ chromosome which is lethal when homozygous. With homozygous $r r, c r$ mutated to $C r$.

Thus, it seems, the total genotype can condition the re-conversion of $\mathrm{cr}$ which has come from $\mathrm{Cr}$ (of gaudens . velans) back to $\mathrm{Cr}$. And it can also condition the mutation of $c r$ to $\mathrm{Cr}$ in the $5 \mathrm{cr} s p 6$ chromosome (of Hookeri and blandina).

\section{DISCUSSION}

The $\mathrm{Cr}$ and $\mathrm{cr}$ genes are both entirely stable in the original forms. They become labile through crossing. In one case they remain virtually unchanged; that is in the hybrid :

\section{CE. (biennis cruciata $\times$ Hookeri) albicans. ${ }^{h}$ Hookeri.*}

In one case the dominant allele remains unchanged while the recessive becomes changed to the dominant; that is in the twin hybrids :

E. (biennis $\times$ Lamarckiana cruciata) albilata and albivelutina.

In this cr-Lamarckiana it is remarkable that the $c r$ gene was very inconstant thirty-eight years ago and often gave more $\mathrm{Cr}$ than $\mathrm{cr}$ offspring. Only after a time did it become stable. And in crossing with $\mathrm{Cr}$ types it always showed itself recessive.

Apart from these exceptions the common behaviour is that both alleles become labile on crossing. And in the same $F_{1}$, even in the same individual, partly $\mathrm{Cr}$ is converted to $\mathrm{cr}$ and partly $\mathrm{cr}$ to $\mathrm{Cr}$. Not only the dominant but also (in other cells) the recessive allele can be active in conversion or prepotent and the dominant allele can be passive in

\footnotetext{
* haplc-Hookeri.
} 


\section{Plate}
A. (Lamarckiana cruciata small-flowered $\times$ pictirubata $F_{\mathbf{1}}$ normal) velans. rubens normal. I $953 / 3^{8}$.
B. (Lamarckiana cruciata small-flowered $\times$ pictirubata $\mathrm{F}_{1}$ cruciata) velans . rubens cruciata. 1953/34.
C. (Pictirubata $\mathbf{F}_{1}$ normal $\times$ sp-blandina cruciata) pingens . ${ }^{h}$ blandina normal. $1953 / 67$.
D. (Pictirubata $\mathrm{F}_{1}$ cruciata $\times$ sp-blandina cruciata) pingens. ${ }^{n}$ blandina cruciata. 1953/44. 

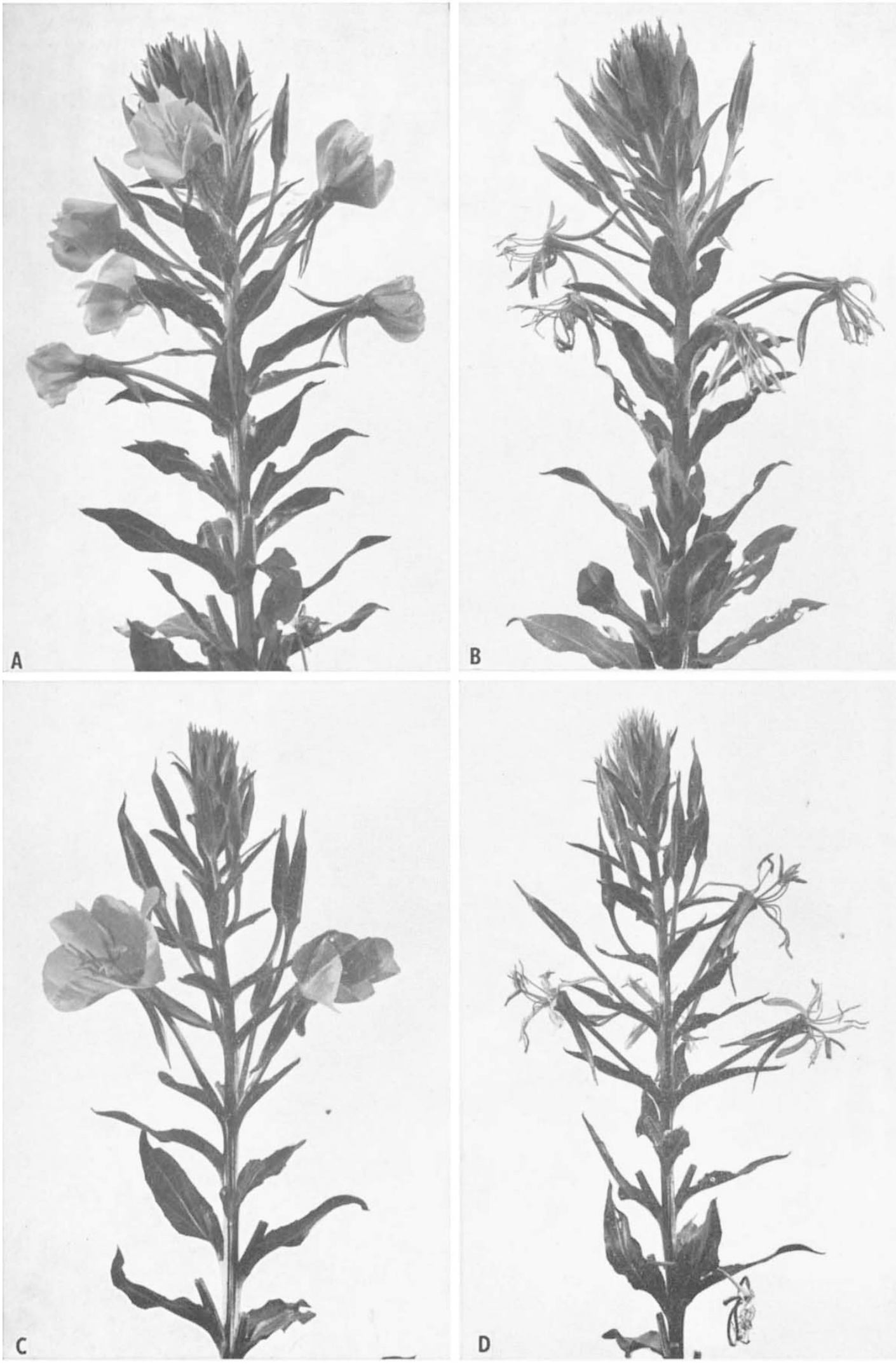
conversion or succumbent. The struggle between the antagonists for prepotency lies at the genotypic level. It is often finished early in development as shown by the uniformity of many $F_{1}$ individuals.

The relation of valencies is of importance only when the conversion from heterozygous to homozygous condition does not take place. Prevalency or dominance belongs to the phenotypic level of activity.

What the intermediate forms of the petals mean is not clear. It is not even clear whether they are expressions of equivalence or of equipotence : (that is to say of physiological activity or of conversion activity). Mosaics of definitive $\mathrm{Cr}$ or $\mathrm{cr}$ zones can, however, arise. These show how late the conversion may occur.

Many observations suggest that the $\mathrm{Cr}$ and $\mathrm{cr}$ alleles may each be composed of a large number of units. Oehlkers has even proposed that the two may differ only in the number of their constituent units. The strongest $C r$ allele would then have the most, and the strongest or the fewest, units.

Attempts to influence conversion by treatment of soaked seeds with high temperatures have not succeeded. How one allele acts on the other in conversion is quite unknown. It is not even known whether homologous segments lie together during the preparation of mitosis or whether the heterochromatin which extends on both sides of the centromere is concerned. Thus, although conversion itself can be regularly demonstrated in Enothera, we still await its explanation.

It is hard to say whether conversion in Enothera might happen in meiosis as well as in mitosis. But it is doubtful whether it has any connection with the irregular or partial and purely meiotic " conversion " recently discussed elsewhere, e.g. in Saccharomyces by Lindegren and Winge ; in Neurospora by Mitchell and Beadle; in Aspergillus by Strickland ; in Drosophila by Goldschmidt.

\section{SUMMARY}

I. In crosses between normal and cruciate types of Enothera, both of them stable, normal $(C r)$ can dominate over cruciate $(c r)$.

2. Commonly the $F_{1}$ is variable in petal form. The normal individuals or parts of individuals then breed as $\operatorname{Cr} C r$, the cruciate as cr cr.

3. The mutational change from hetero- to homo-zygote is described as Somatic Conversion.

4. The dominant allele is more often active or prepotent in conversion than the recessive. But the recessive can also be prepotent.

5. Thus the process of conversion happens at the genotypic level. It has nothing to do with the phenotypic valency relation of dominant to recessive.

6. In the complex rubens of $E$. biennis, $c r$ is linked with $s p:$ or thus belongs to the 5.6 chromosome, either to the 5 or the $6 \mathrm{arm}$.

7. The stability of the $\mathrm{cr}$ allele is influenced by the genotype as a 
whole but the empirical observations do not reveal how somatic conversion takes place.

Acknowledgment.--I wish to thank Professor C. D. Darlington for the translation of the German text.

\section{REFERENCES}

kOWALEWICZ, Rose. 1955. Entwicklungsgeschichtliche Studien an normalen und cruciaten Blüten von Epilobium und EEnothera. Planta, 46, 569-603.

oehlkers, F. I930a. Studien zum Problem der Polymerie und des multiplen

Allelomorphismus. I. Z.f. Bot., 22, 473-537.

oEHLKERS, F. I930 $b$. Ebenda, 23, 967-1003.

oeHLkers, F. 1935. Die Erblichkeit der Sepaloidic bei Enothera und Epilobium. Ebenda, 28, 16I-222.

oEHLKERs, F. 1938. Über die Erblichkeit des cruciata-Merkmals bei den Enotheren.

Eine Erwiderung. Z.f. Vererbungslehre, 75, 277-297.

RENNER, O. 1937. Über Enothera atrovirens und über somatische Konversion im

Erbgang des cruciata-Merkmals der Enotheren. Z. Vererbungslehre, 75, 9I-I 24.

RENNER, O. I939. II. Über gigas- und hemigigas-Formen und ihre Verwendung zur Untersuchung des cruciata-Merkmals. Flora (Jena), I33, 21 5-238.

RENNER, O., AND SENSENHAUER, R. I942a. III. Versuche über den Erbgang des cruciata-Merkmals der Enotheren. Weitere Belege für somatische Konversion.

Z. Vererbungslehre, $80,570-589$.

RENNER, o., - I $1942 b$. IV. Beiträge zur Kenntnis des cruciata-Mcrkmals der

Enotheren. Gigas-Bastarde. Labilität und Konversibilität der $\mathrm{Cr}$-Gene.

Ebenda, 80, 590-6 I I.

RENNER, O., - I957. V. Über den Erbgang dcs cruciata-Mcrkmals der Enotheren. Planta (Berl.), 48, 343-392.

RENNER, O., - I958c. VI. Verbindungen der Enothera Lamarckiana mut. blandina. Z. Vererbungslehre, 89, I4-35.

RENNER, o., I $1958 d$. VII. Verbindungen der Enothera Hookeri, franciscana und purpurata. Flora (Jena), I45, 339-373.

RENNER, o., - VIII. Verbindungen der $E$. atrovirens, und Rückblick. Z. Vererbungslehre, im Druck.

Winkler, H. 1930. Die Konversion der Gene. Jena.

\section{Appendix}

Goldschmidt, R. B. I958. Genic conversion in Enothera? Am. Nat., 92, 95-I04. LINDEGREN, c. C. Priority in gene conversion. Experientia (Basel), in the press. LINDEGREN, c. C. I957. The integrated ccll. Cytologia (Tokyo), 22, 4I 5-44I. 